\title{
Dental students' self-perceived competency and usage of the internet for learning and evaluation purposes - Part 2
}

SADJ August 2020, Vol. 75 No. 7 p377 - p381

LM Sykes ${ }^{1}$, TC Postma², A Uys ${ }^{3}$, P Brandt $^{4}$, E Crafford ${ }^{5}$

\section{ABSTRACT}

Many dental lecturers are moving away from providing hand-out notes to their students and are rather opting for posting lecture material and tutorials on the internet using the various university platforms such as clickUP.

At the same time a number of students have queried the need to purchase the prescribed text books due to their high costs, and dated content. The presumption is that all students have unrestricted and equal access to this material, and are competent using digital technology for learning and assessment, however there has been no formal investigation into whether this is so.

Student access and usage was reported on in Part I of this study. The present paper investigated students' preferences with regards to the mode of learning material, and their self-perceived competencies in using the internet for various academic purposes. The project took the form of an anonymous, structured questionnaire that was given to all dental students from the second to the fifth year of study.

\section{Author affiliations:}

1. Leanne M Sykes: BSc, BDS, MDent, IRENSA, Dip Forensic Path, Dip ESMEA, Head of Department of Prosthodontics, University of Pretoria, Pretoria, South Africa.

ORCID Number: 0000-0002-2002-6238

2. Thomas C Postma: MChD, DHSM, PhD, Head Clinical Unit, Department of Dental Management Sciences, University of Pretoria, Pretoria, South Africa.

3. André Uys: B.Sc., BChD. Dip.Odont. (Materials), Dip. Odont (Endo), M.Sc. (Odont.), PhD, Department of Oral Pathology and Oral Biology, Faculty of Health Sciences, University of Pretoria, Gauteng, South Africa.

4. Paul Brandt: BChD (Stell), MSc (Odont), Adv Dip Aesthet Med (FPD), Department of Restorative Dentistry, University of Pretoria Pretoria, South Africa.

5. Elmine Crafford: $B C h D, B C h D$ Hons, Oral Medicine, MChD OMP Senior Specialist Department of Oral Medicine and Periodontics, University of Pretoria, Pretoria, South Africa.

Corresponding author: Leanne M Sykes

Head of Department of Prosthodontics, University of Pretoria, Pretoria, South Africa.

Email: leanne.sykes@up.ac.za

Author contributions:

1. Leanne M Sykes: First author - $40 \%$

2. Thomas C Postma: Second author - $30 \%$

3. André Uys: Third author - $10 \%$

4. Paul Brandt: Fourth author - $10 \%$

5. Elmine Crafford: Fifth author - $10 \%$
Results revealed that over $90 \%$ of the students feel competent to access and use internet search engines for research and assignments, to connect with friends, and to download or watch videos. Slightly less (between 7090\%) were confident using it for independent research, learning from lecture material, using e-dictionary, carrying out searches to learn extra material, completing short quizzes and assignments, or undertaking independent learning and reading.

Almost all students needed to access the internet on a daily or weekly basis for work related issues, yet at least $40 \%$ reported to not being able to do so at times or in venues that suited their programs. Lecturers need to be aware of this to ensure these students are not disadvantaged in comparison to their peers if they do not submit requisite material on time.

The university has pledged their commitment towards changing traditional teaching methods and embracing more blended learning platforms, as well as to helping students make up for the lost time due to the Corona virus pandemic. However, now more than ever they need to work together to ensure that all students have the necessary skills and technology needed to use the online platforms, and to provide the necessary tuition and changes if they wish to be truly committed to the wellbeing and education of their students.

\section{INTRODUCTION}

The strategic drive towards online learning, ${ }^{1}$ requires Universities to develop the necessary competencies to empower students to reap a multitude of benefits. ${ }^{2,3}$

In line with this, many academic institutions have been encouraging lecturers to implement flipped-learning-methodologies. The aim being that students will carry out pre-class groundwork, come to the class prepared and ready to engage with the lecturer, and then consolidate their knowledge through after class revision.

Preparation involves accessing information posted electronically, including reading selected chapters from ebooks, or PDF notes, watching Power Point slide 
shows, videos and links to YouTube presentations or visiting recommended internet study sites. During lecture time, students have opportunities to ask questions rather than sitting through a traditional formal lecture. Thereafter they will be given online revision exercises, assignments and assessments to complete in order to consolidate their new knowledge and provide the lecturers with a form of continuous evaluation. Many lecturers have been moving away from providing hand-out notes to their students and have opted for posting lecture material and tutorials online, in addition students have queried the need to purchase prescribed textbooks due to costs and dated content.

Since the increase in internet usage, it has become an important medium for communication as it is easy to access all kinds of information quickly and directly. It allows information to be used for entertainment, leisure, social, educational and research purposes.

Park (2009) suggested that its two greatest benefits are in communication and information exchange. Its most valuable utility lies in the ever-growing information stockpile with boundless communication potential that allows for interactive online learning and research, innovation, and enhanced scholarship across continents. ${ }^{4}$

Online learning can additionally be used as a tool to access the latest news on a global scale, allowing for rapid dissemination of information to a wide audience. ${ }^{4}$ Not only does this have the potential to improve the quality of education, but it also allows students to augment their knowledge through self-study and critical appraisal of content. It also holds promise to enhance problem-solving, creative thinking and collaboration. ${ }^{5,6}$ Despite obvious advantages, the uptake and usage has been slow and erratic amongst both staff and students.

The outbreak of the novel Coronavirus (C19) and the enforced country wide shut down, has meant that lectures and clinical sessions have had to be cancelled and there is no longer the opportunity for active engagement in the classroom. Such circumstances compelled educators to explore and expedite online possibilities of teaching, learning and assessment. ${ }^{7}$

The presumption is that all students possess the requisite technological skills and competencies, and are comfortable using and interacting on the various internet platforms. Unfortunately, this strategy requires an increased amount of self-regulated learning,, ${ }^{8,9}$ which may result in cognitive overload and a breakdown in the learning process ${ }^{1}$ due to reduced support from a lecturer. ${ }^{10}$

It is indeed not easy for a novice to sift through a magnitude of information and to decide what is important. ${ }^{10}$ This situation negatively influences self-efficacy belief, motivation, ${ }^{11}$ and perceived self-competence, ${ }^{13}$ and may result in decreased performance in this context. ${ }^{13}$ Struggling with the technical aspects of technology on top of the requirements of the cognitive load that selfstudy requires, will further exacerbate the whole situation. $^{1}$
Hence, this study aimed to gauge online learning requirements as well the self-perceptions of dental students about their digital competence in a learning environment. The hypothesis was that dental students do possess some form of digital competence, but their ability may be lacking when it comes to higher order self-study on digital platforms. The results of this needs assessment study could inform further action required to inform ongoing curriculum improvement. ${ }^{14}$

\section{MATERIALS AND METHODS}

\section{Study outline and sample selection}

A cross-sectional survey was administered in the latter half of 2017 to all dental students from the second to the fifth year of study at the Oral and Dental Hospital of the University of Pretoria. The estimated target was 240 students, evenly spread through the years of study (average 60 students per year).

Students were assured that all questionnaires would remain anonymous and all comments would be kept confidential. Students who had related concerns were encouraged to seek assistance from a lecturer or the researchers.

\section{Questionnaire}

A structured questionnaire was given to all students which included a brief demographic survey (sex, year of study and place of residence). The survey also enquired the frequency of use of the online resources in the context of their studies (refer to the leftmost column in Table 1 for the detailed questions asked).

Students could either mark $0=$ Never, $1=$ Once or twice a semester, 2=Monthly, 3=Weekly, $4=$ Daily. In addition, their self-perceived competence in using the internet (in different ways), for study purposes, was also gauged (refer to the leftmost column in Table 2 for the detailed questions asked).

All questions were rated on a 5-point Likert scale: $0=$ Strongly Disagree, 1=Disagree, 2= Neutral, 3=Agree, $4=$ Strongly Agree. Zero to three and four and five were collapsed together to form "Low" and "High" categories of perceived self-competence, respectively.

The statistical analysis was purely descriptive using frequency distributions.

\section{RESULTS}

A total of 218 dental students responded $(87.2 \%$ response rate). Not all student answered all the questions, hence the percentages in the results below does not reflect the 218 (total) responses, only those who answered each question.

The demographic characteristics of the sample can be viewed in Figure 1. Respondents were evenly spread in terms of year of study ranging between 23.5 $-27.6 \%$ from the second to the fifth year. Only $26.4 \%$ were male and the rest female. 




Figure 1. Year of study

Table 1 indicates the various academic requirements that involve accessing the internet for learning and assessment purposes, as well as the frequency of use.

Table 2 contains a summary of students' agreement about their competence in e-learning skills (in descending order).

Highest agreement was achieved for the general use of search engines, the downloading of pictures, learning from printed material, networking using messaging applications, and identification and downloading of relevant videos.
Reading scientific papers related to lecture material and the conducting of self-directed learning on recent information and the latest developments received the lowest confidence ratings. More than 60 students indicated a feeling of low self-competence in this regard.

\section{DISCUSSION}

This study aimed to gauge online learning requirements and perceived self-competence of dental students to utilise certain elements of the online learning space. This needs assessment was conducted to help inform curriculum transformation ${ }^{14}$ in the context of online learning. High quality patient care is only possible if dentists have received high quality teaching in their undergraduate years. ${ }^{15}$ Varied responses of online learnng requirements (Table 1) are reflective of the collated results of the variable requirements for different years of study and different preferences among students. What is more important to note is that, at the time of this study, there was not a high daily, or even a weekly demand to engage with online resources, except for reading messages and announcements. There were also not too many true blended learning activities in the programme which, at that time, relied predominantly on teacher-centred lecture periods and limited online requirements.

\begin{tabular}{|c|c|c|c|c|c|}
\hline Frequency of need to access the internet for: & $\begin{array}{l}\text { Never } \\
0\end{array}$ & $\begin{array}{l}\text { Once or } \\
\text { twice/semester } \\
1\end{array}$ & $\begin{array}{l}\text { Monthly } \\
2\end{array}$ & $\begin{array}{l}\text { Weekly } \\
\quad 3\end{array}$ & $\begin{array}{c}\text { Daily } \\
4\end{array}$ \\
\hline Acquiring lecture materials, study guides and schedules. & $0 \%$ & $2.8 \%$ & $3.2 \%$ & $50.5 \%$ & $42.7 \%$ \\
\hline Completion of quizzes. & $2.3 \%$ & $22.5 \%$ & $41.7 \%$ & $23.9 \%$ & $8.7 \%$ \\
\hline $\begin{array}{l}\text { Completion/submission of assignments that count for } \\
\text { marks }\end{array}$ & $0.5 \%$ & $37.2 \%$ & $34.4 \%$ & $21.6 \%$ & $6.0 \%$ \\
\hline Checking marks on clickUp & $1.8 \%$ & $5.5 \%$ & $29.4 \%$ & $45.6 \%$ & $17.0 \%$ \\
\hline $\begin{array}{l}\text { Reading announcements / general info on modules or } \\
\text { from the university }\end{array}$ & $0.9 \%$ & $2.8 \%$ & $6.9 \%$ & $33.5 \%$ & $55.5 \%$ \\
\hline Use of the computers in the computer labs on campus & $29.8 \%$ & $32.5 \%$ & $17.05 \%$ & $12.4 \%$ & $8.5 \%$ \\
\hline
\end{tabular}

\section{Table 2. Student agreement on competence levels related to e-learning.}

\begin{tabular}{|c|c|c|c|c|c|}
\hline Question & \multicolumn{5}{|c|}{ Agreement } \\
\hline & & \multicolumn{2}{|c|}{ Low (0-2) } & \multicolumn{2}{|c|}{ High (3 and 4$)$} \\
\hline I feel competent to: & & $\mathrm{n}$ & $\%$ & $\mathrm{n}$ & $\%$ \\
\hline Use search engines like Google, Yahoo etc. & $\mathrm{N}$ & 10 & $4.7 \%$ & 205 & $95.3 \%$ \\
\hline $\begin{array}{l}\text { Download pictures or photos from the Internet for } \\
\text { research and assignments. }\end{array}$ & $\mathrm{N}$ & 17 & $7.9 \%$ & 199 & $92.1 \%$ \\
\hline $\begin{array}{l}\text { Learn from lecture material provided to me in } \\
\text { printed form. }\end{array}$ & $\mathrm{N}$ & 17 & $7.9 \%$ & 199 & $92.1 \%$ \\
\hline $\begin{array}{l}\text { Establish a connection with my friends on the Internet } \\
\text { via MSN, Yahoo Messenger, Facebook, WhatsApp etc. }\end{array}$ & $\mathrm{N}$ & 19 & $8.8 \%$ & 197 & $91.2 \%$ \\
\hline $\begin{array}{l}\text { Identify, download or watch relevant videos related to my } \\
\text { studies. }\end{array}$ & $\mathrm{N}$ & 21 & $9.7 \%$ & 196 & $90.3 \%$ \\
\hline Do research on the Internet. & $\mathrm{N}$ & 28 & $12.1 \%$ & 204 & $87.9 \%$ \\
\hline $\begin{array}{l}\text { Learn from lecture material provided to me on } \\
\text { electronic platforms. }\end{array}$ & $\mathrm{N}$ & 34 & $15.7 \%$ & 182 & $84.3 \%$ \\
\hline Use an e-dictionary to look up terms I do not understand. & $\mathrm{N}$ & 36 & $16.8 \%$ & 178 & $83.2 \%$ \\
\hline $\begin{array}{l}\text { Learn more about topics that were explained in lectures, } \\
\text { or seen clinically, and which and took my attention. }\end{array}$ & $\mathrm{N}$ & 37 & $17.1 \%$ & 179 & $82.9 \%$ \\
\hline Share any kind of data with my friends on the Internet & $\mathrm{N}$ & 42 & $19.4 \%$ & 174 & $80.6 \%$ \\
\hline $\begin{array}{l}\text { Complete short quizzes and assignments on work } \\
\text { I have to research myself }\end{array}$ & $\mathrm{N}$ & 51 & $23.6 \%$ & 165 & $76.4 \%$ \\
\hline $\begin{array}{l}\text { Conduct self-directed learning on recent information } \\
\text { and the latest developments }\end{array}$ & $\mathrm{N}$ & 63 & $29.2 \%$ & 153 & $70.8 \%$ \\
\hline $\begin{array}{l}\text { Read scientific papers related to lecture material from } \\
\text { different web sites }\end{array}$ & $N$ & 67 & $30.9 \%$ & 150 & $69.1 \%$ \\
\hline
\end{tabular}


The results of this study show that the respondents had a lot of confidence that they were competent in performing basic digital literacy tasks such as online searches, downloading content, interacting socially, doing online research, dictionary lookups and exploring content in a broader way. This is not surprising as many of the students grew up with such technology and may have also received some training in this regard.

Self-confidence in online learning abilities, however, appeared to have dropped among a greater proportion of students when it came to completing quizzes that required self-study, conducting research on latest developments, and reading scientific papers from different resources.

These tasks require higher cognitive functioning and considerable self-control, focus and dedication. Tasks like these can easily cause students who lack selfregulation skills to lose their motivation, eventually give up and abandon learning because they doubt their abilities. ${ }^{13}$

It is surely significant if sixty, or so, dental students out of 218 do not have self-competency-belief to perform such tasks and will require some remediation. They maybe lacking in this regard because they are not regularly required to do online self-study.

The problem is clearly not seated in the technology itself but rather in the students' struggle to identify and prioritise important knowledge. ${ }^{11}$ This can only be overcome through repeated practice in context with proper scaffolding and support structures to prevent consistent cogitative overload. ${ }^{10}$

To achieve this, authentic exercises requiring these skills will have to be rolled out as part of teaching, learning and assessment, for example, to continuously look for the latest evidence ${ }^{16}$ to diagnose and to perform procedures.

This will require reading scientific literature and to evaluate new knowledge against existing knowledge. To achieve this, students will have to learn life-skills such as selfcontrol, patience, focus and dedication to enhance their online learning skills. ${ }^{17}$

It will also require teachers to make a paradigm shift away from teacher-centeredness towards cultivating lifelong learning. ${ }^{18}$ It is presumed that students know where and how to look for information on the internet, and thereafter how to communicate and interact with their peers and supervisors as corroborated by the results of this study. Increased focus should therefore go into teaching students the use of library resources even from remote locations.

They need to acquire the ability to use online and offline databases as well as web search-engines effectively to reach the information they need, and to then critically appraise it and extract the necessary, relevant and accurate data amongst a sea of irrelevant communications. According to Nentwich (2003) the ability to find, organize, structure and evaluate information is critically important, ${ }^{19}$ requiring three important internet literacies.
Critical literacy, firstly, requires a deep, socially contextualized, and updated comprehension of the internet. Creative literacy, secondly, requires the aptitude to experiment online in order to recognise and construct information. Network literacy, thirdly, necessitates an ability to effectively and apply internet technologies to communicate and collaborate to construct and share knowledge in an ethical way. ${ }^{20}$

In striving for educational advancement, many lecturers at the School of Dentistry, University of Pretoria were starting to move away from handing out notes and manuals and were uploading lecture material and related references on on-line platforms such as clickUP for students to access before and after the lectures.

The aim was to have learners read through the material and prepare for each lecture beforehand, and to then use the lecture time to get clarity and additional information. Other advantages of an online approach are that notes can easily be modified with current information, augmented with explanations and illustrations of associated clinical procedures, materials and techniques, and reference sources added or updated as needed. They are also using various other virtual / internet sites such as email, and WhatsApp for posting assignments, giving feedback, and displaying grades.

Advantages are that they can communicate on a personal level or through group messages depending on the need for privacy and confidentiality. These can also be used to post revision exercises and quizzes and to monitor how learners are progressing with their studies. Lecturers can reach a wider audience on a more personal level, while learners have to ability to study at their own pace and to revisit topics that they find confusing or difficult to conceptualize.

The teacher's role is to impart knowledge using the most effective teaching strategies for each purpose. In addition, they should discuss learning goals, provide explanations, pose questions, provide sources for further reading, and if possible, have mechanisms that allow for interaction and evaluation. ${ }^{15}$ Clinical teachers have an inherent obligation to maintain their own competence as teachers and to continually improve their tuition skills and methods to be in keeping with learner's requirements. ${ }^{21}$

The current COVID-19 disruption has drastically changed the need for self-study and online learning, which may have a lasting impact in higher education. The current study suggests that students were not necessarily well prepared for these increased demands. Students were sent home during lockdown periods and if this study was repeated today, the actual numbers would be worse because of sub-par access to information technology and living conditions of many of the learners. While the school cannot do much about the present situation, it may be necessary to implement measures, and structure both immediate and ongoing courses to ensure all students acquire the necessary skills and competencies to use the internet to its full potential. This will be crucial for the current year when there is going to be a huge demand for "catch up" learning. 
Although this research was conducted prior to the pandemic, it provides valuable insights in how students were prepared for independent self-study using online platforms. The 2020 second year cohort, who was part of this study, is now in final year and there is no reason to believe that the traditional teaching and learning strategies employed in 2017 were much different from what happened until the start of 2020 .

The forced isolation of staff and students has made the findings crucial for lecturers to ascertain whether the new initiatives will be of educational benefit, and to identify problems they may have with this.

\section{CONCLUSION}

Most students had high levels of confidence in the basic digital literacy used in everyday life, but need additional development in higher order skills such as self-study, conducting research on latest developments and reading and interpreting scientific papers from different resources.

These skills should be built into new curricula and be developed through repeated practice with proper scaffolding and learner support to increase self-efficacy belief and self-competence. Changing the attitudes of lecturing staff to adopt such strategies in an appropriate way will be crucial.

\section{References}

1. Panigrahi $R$, Srivastava $P R$, Sharma D. Online learning: Adoption, continuance, and learning outcome-A review of literature. International Journal of Information Management. 2018 Dec 1; 43: 1-4.

2. Tsai CW. Applying online competency-based learning and design-based learning to enhance the development of students' skills in using PowerPoint and Word, self-directed learning readiness, and experience of online learning. Universal Access in the Information Society. 2018 Nov 1; 1-2.

3. Ng'ambi D, Brown C, Bozalek V, Gachago D, Wood D. Technology enhanced teaching and learning in South African higher education-A rear-view of a 20 year journey. British Journal of Educational Technology. 2016 Sep; 47(5): 843-58.

4. Dogruera N, Eyyamb R, Menevis I. The use of the internet for educational purposes. Social and Behavioural Sciences. 2011; 28: 606-11.

5. Charp C. The millennium classroom. The Higher Education Journal. 2000; 27(10): 10-12.

6. Ciglaric M, Vidmar T. The use of Internet technologies for teaching purposes. European Journal of Engineering Education. 1998; 23(4): 497-503.

7. Huang $\mathrm{RH}$, Liu DJ, Tlili A, Yang JF, Wang HH. Handbook on Facilitating Flexible Learning During Educational Disruption: The Chinese Experience in Maintaining Undisrupted Learning in COVID-19 Outbreak. Beijing: Smart Learning Institute of Beijing Normal University. 2020.

8. Barak M, Hussein-Farraj R, Dori YJ. On-campus or online: examining self-regulation and cognitive transfer skills in different learning settings. International Journal of Educational Technology in Higher Education. 2016 Dec; 13(1): 35.

9. Adam NL, Alzahri FB, Soh SC, Bakar NA, Kamal NA. Selfregulated learning and online learning: a systematic review. In International Visual Informatics Conference. 2017 Nov 28; 143-154.

10. Sweller J, van Merriënboer JJ, Paas F. Cognitive architecture and instructional design: 20 years later. Educational Psychology Review. 2019 Jan 22; 1-32.
11. Aharony N, Gazit T. Students' information literacy selfefficacy: An exploratory study. Journal of Librarianship and Information Science. 2020 Mar; 52(1): 224-36.

12. Burns RA, Crisp DA, Burns RB. Competence and affect dimensions of self-concept among higher education students: a factorial validation study of an academic subject-specific self-concept. European Journal of Psychology of Education. 2018 Oct 1; 33(4): 649-63.

13. Bradley RL, Browne BL, Kelley HM. Examining the influence of self-efficacy and self-regulation in online learning. College Student Journal. 2017 Dec 1; 51(4): 518-30.

14. McKenney S, Reeves TC. Conducting educational design research $2^{\text {nd }}$ ed. Routledge. 2018.

15. Cornelia RM, Fluit D, Bolhuis S, Grol R, Laan R, Wensing M. Assessing the Quality of Clinical Teachers. A Systematic Review of Content and Quality of Questionnaires for Assessing Clinical Teachers. J Gen Intern Med. 2010; 25(12): 1337- 45.

16. Lalla RV, Li EY, Huedo-Medina TB, MacNeil RL. Evaluation of an Experiential and Self-Learning Approach to Teaching Evidence-Based Decision Making to Dental Students. Journal of dental education. 2019 Oct 1; 83(10): 1125-33.

17. Gorbunovs A, Kapenieks A, Cakula S. Self-discipline as a key indicator to improve learning outcomes in e-learning environment. Procedia-Social and Behavioral Sciences. 2016 Oct 5; 231: 256-62.

18. Carlson ER. Lifelong Learning: A Higher Order of Consciousness and a Construct for Faculty Development. Journal of Oral and Maxillofacial Surgery. 2019 Oct 1; 77(10): 1967-e1.

19. Nentwich M. Cyberscience - Research in the age of the Internet. Austrian Academy of Science Press, editor. Vienna. 2003.

20. Burgess J. Blogging to learn, learning to blog. Use of Blogs. Bruns A, Jacobs J, editor. New York: Peter Lang; 2006.

21. Snell L, Tallett S, Haist S, Hays R et al. A review of the evaluation of clinical teaching: New perspectives and challenges. Med Educ. 2000 Oct; 34(10): 862-70. 